\title{
BOULDER POLYGONS AND STRIPES IN THE CAIRNGORM MOUNTAINS, SCOTLAND
}

\author{
By R. BRUCE KING \\ (Kerry Stables, Lammas Lane, Esher, Surrey, England)
}

\begin{abstract}
Measurements of widths, diameters and boulder sizes of patterned ground in the Cairngorm Mountains indicate two sorts of stripes and polygons (fine and coarse). Pipkrake and boulder-inclination observations and measurements suggest that fine polygons are produced by heave and their sizes are dependent upon the frequency of boulders large enough to be resistant to heave, which in turn depends upon climatic severity. The lack of orientation, angle of boulder inclination, hemispherical shape, high relative size dispersion and lithological dependence of coarse polygons indicate a selective weathering origin. The frequency of low inclination of boulders in stripes suggests an origin due to solifluction, whereby large immobile or relatively slower-moving boulders impede soil (and smaller boulder) movements and control stripe spacing. Movement observation and lichenometry indicate that fine polygons and stripes and bare coarse polygons are active at the present time and that coarse stripes and vegetated coarse polygons probably date from the Little Ice Age.

RÉsumé. Polygones de pierres et sols striés dans les Cairngorm Mountains, Écosse. Les mesures de largeurs, diamètres, calibre de galets de sols géométriques dans les Cairngorm Mountains montrent deux types de sols striés et polygonaux (fins et grossiers), les mesures et les observations de l'inclinaison des pipkrakes et des blocs permettent de penser que les polygones fins résultent des mouvements verticaux et que leur grandeur dépend de la fréquence des blocs suffisamment larges pour résister au soulèvement qui dépend à son tour de la sévérité climatique. L'absence d'orientation, l'angle d'inclinaison des blocs, la forme hémisphérique, la haute dispersion relative des grandeur et la dépendance lithologique des polygones grossiers indiquent une origine d'altération sélective. La fréquence de la faible inclinaison des blocs dans les sols striés suggère une origine due à la solifluxion; les blocs relativement grands et mobiles la contrariant et réglant les intervalles entre les striés. Étude des mouvements et la lichénométrie indiquent que les polygones et sols striés fins ainsi que les polygones grossiers nus sont actuellement actifs tandis que les polygones grossiers pris par la végétation dateraient du petit âge glaciaire.
\end{abstract}

Zusammenfassung. Stein-Polygone und -Streifen in den Cairngorm Mountains, Schottland. Messungen von Abständen, Durchmessern und Steingrössen der Strukturböden in den Cairngorm Mountains weisen zwei Arten von Streifen- und Polygonböden aus: feine und grobe. ,Pipkrake“ (Bodensondierung) sowie Beobachtungen und Messungen der Steinneigungen laggen vermüten, dass die feinen Polygone durch Hebung hervorgerufen werden und dass ihre Grösse von der Häufigkeit solcher Steine abhängt, die gross genug sind, um von der Hebung nicht erfasst zu werden; diese Häufigkeit hängt ihrerseits von der Rauhigkeit des Klimas ab. Das Fehlen einer Regelung, der Winkel der Steinneigung, der halbkugelförmige Querschnitt, die starke Streuung der Relativgrössen und die lithologische Abhängigkeit der groben Polygone weisen auf einen Ursprung durch selektive Verwitterung hin. Die Häufigkeit geringer Neigung der Steine in Streifen lässt auf eine Entstehung durch Solifluktion schliessen, wobei grosse unbewegliche oder verhältnismässig langsam bewegte Steine die Bewegung des Bodens (und kleinerer Steine) verhindern und den Abstand der Streifen regeln. Beobachtungen der Bewegung und Flechtenmessungen weisen darauf hin, dass feine Polygone und Streifen sowie nackte grobe Polygone zur Zeit aktiv sind und dass grobe Streifen und bewachsene grobe Polygone wahrscheinlich aus der Kleinen Eiszeit stammen.

\section{INTRODUCTION}

The climate of the Cairngorm Mountains resembles Tricart's (1967) "mountainous variety" of the "humid periglacial climates with a marked winter", i.e. the mean annual temperature is about $2-5{ }^{\circ} \mathrm{C}$, * annual precipitation is about $\mathrm{I} 600-2400 \mathrm{~mm}$, there is no permafrost and most freeze-thaw oscillations, which do not penetrate deep into the soil, are equinoctial. The area could also be ascribed to Tricart's Kerguelen tundra morphogenetic province, since there is considerable frost shattering, high humidity, strong winds affecting and limited by the vegetation and frequent pipkrake. Although many periglacial features are found (King, unpublished), the amount of patterned ground, other than lobes, is disappointing, which seems to be due to three factors: vegetation, ground slope and parent material. In order to observe polygons and stripes, the ground must be completely or selectively denuded, a situation which is only extensively found above $900 \mathrm{~m}$. Furthermore, polygons are not found

* There are no long climatic records. 
on slopes greater than $5^{\circ}$. Stripes are found on slopes up to $18^{\circ}$ but above $10^{\circ}$ the lobate form is more common (King, in press). Polygons and stripes are therefore largely restricted to the plateau over $900 \mathrm{~m}$. The higher parts of the plateau consist of fields of well-rounded granitic boulders. The lower parts consist of coarse feldspathic sand. Polygons are found at the boundary between these two parent materials and also where boulders occur amongst the feldspathic sand, especially if the latter is waterlogged. At the former environment, polygons consist of pockets of sand amongst the felsenmeere, here called coarse polygons (Fig. I), and at the latter they consist of boulder rings surrounding feldspathic sand, here called fine polygons (Fig. 2). The basic difference between these two types is the ratio of boulders to sand. The centres of most coarse polygons are vegetated but, in one shallow valley bottom (on the plateau), polygons with the same form and about the same size as coarse polygons contain bare centres and very few stones or boulders.

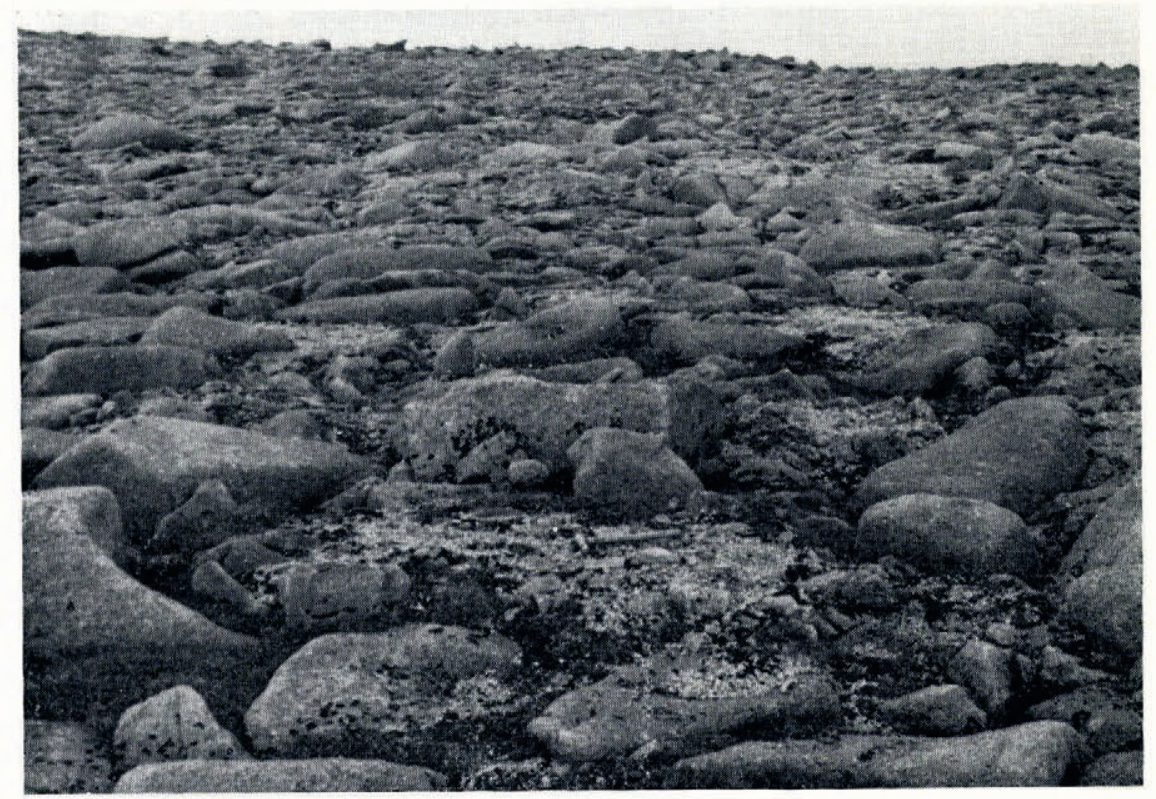

Fig. I. Denuded coarse polygons on the Braeriach plateau.

There are also two different types of stripe. Coarse stripes display alternate bare and vegetated stripes (Fig. 3). The bare stripes possess very little soil and contain coarser stones and boulders than the vegetated ones. Fine stripes are lines (in the direction of strongest declivity) of mostly angular stones in a feldspathic sandy matrix (Fig. 4).

The boulders in the centres of coarse polygons and those forming the vegetated coarse stripes appear to be smaller than their bare borders (Fig. 5) and a $\chi^{2}$ test, using a probability criterion of 0.005 , showed this to be so.

\section{SizES}

25 widths or diameters were measured from each of four sample sites of each patterned ground type. Polygon measurements were restricted to level ground in order to avoid downslope polygon elongation, and in all measurements the shortest diameter was recorded. The distributions were found to fit logarithmic normal curves (Figs. 6 and 7). Means and standard deviations are shown in Table I. There are not enough bare coarse polygons or fine stripes to do an analysis. 


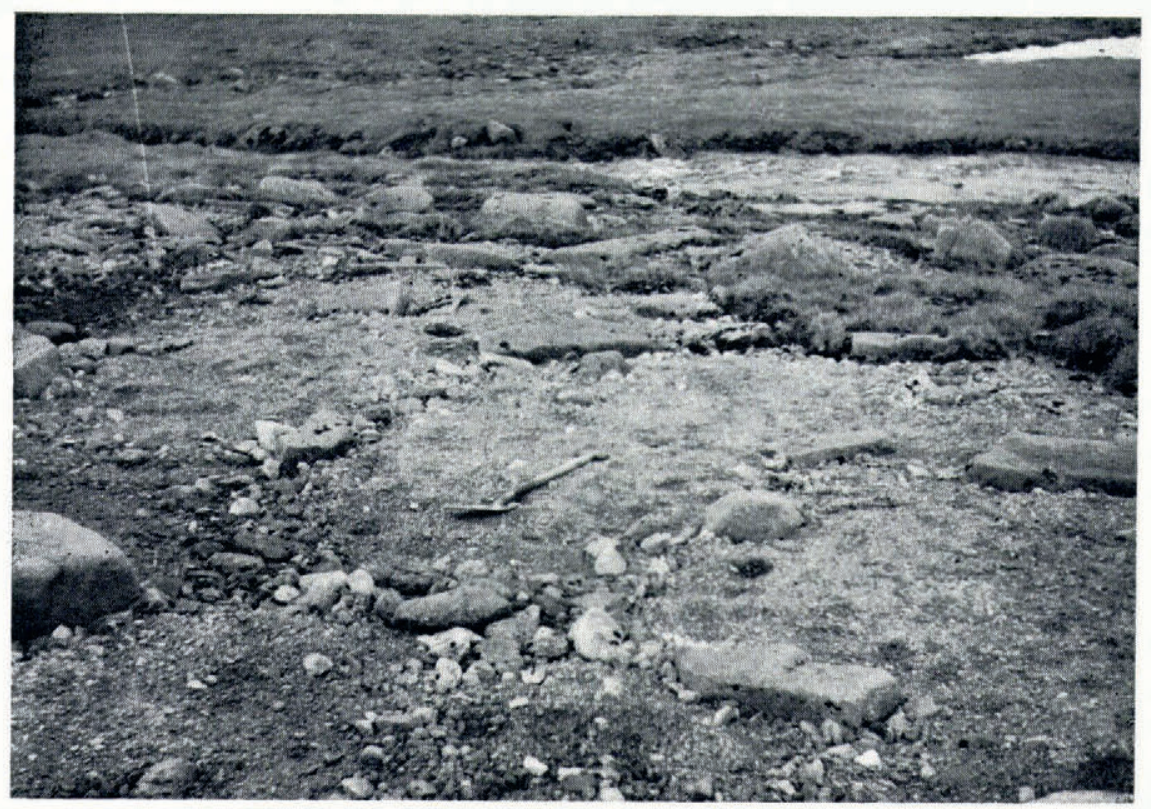

Fig. 2. Fine polygons in the Feith Buidhe valley.

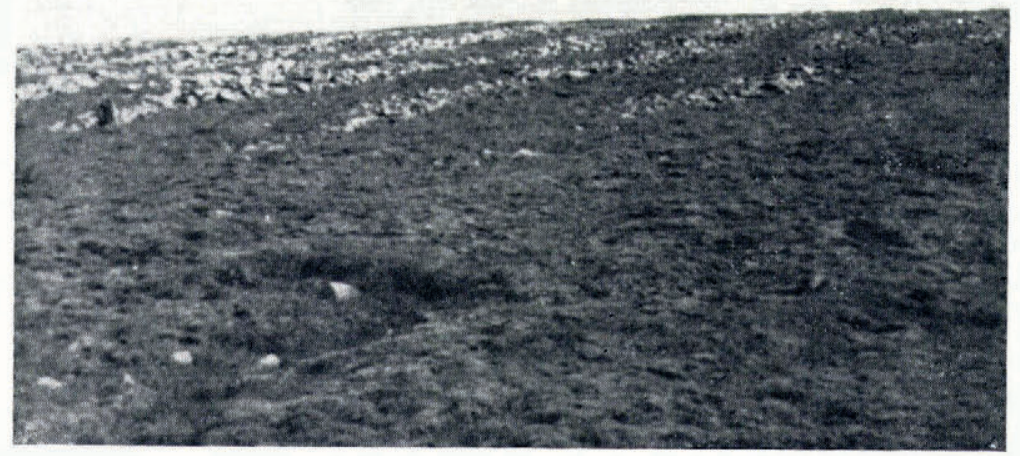

Fig. 3. Coarse stripes on Carn Ban Mor. 


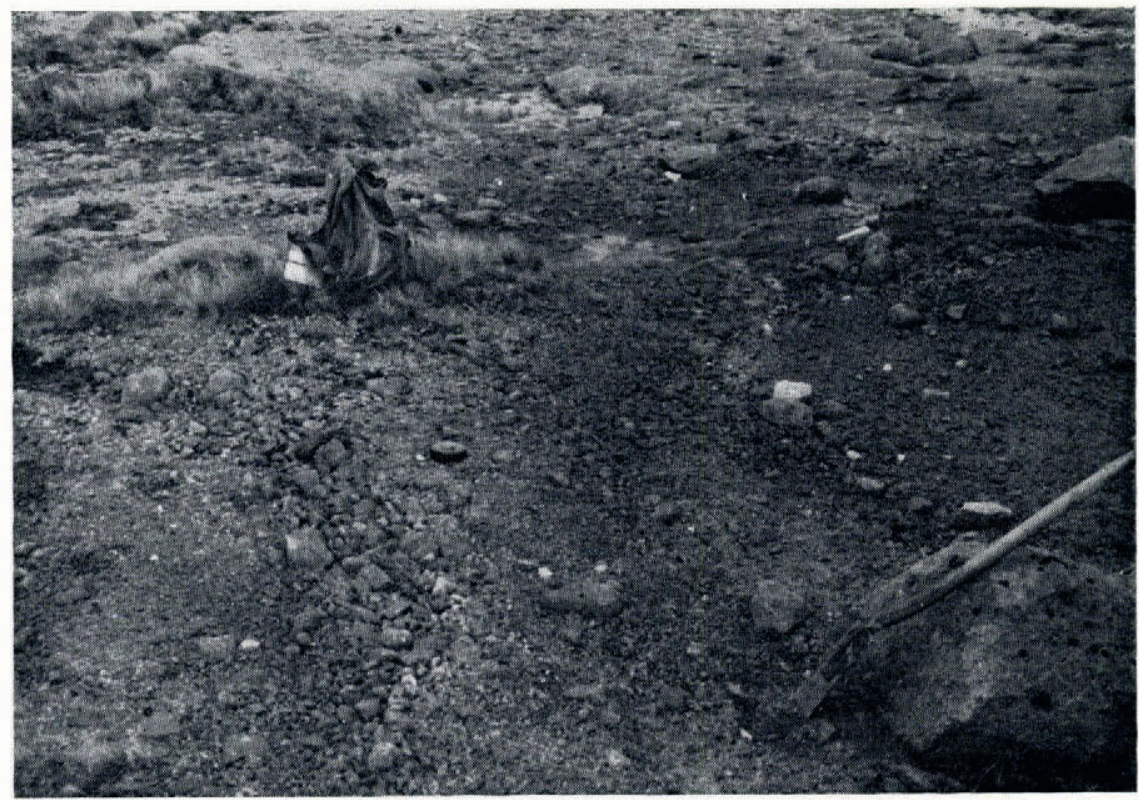

Fig. 4. Fine stripes near Cairn Lochan.

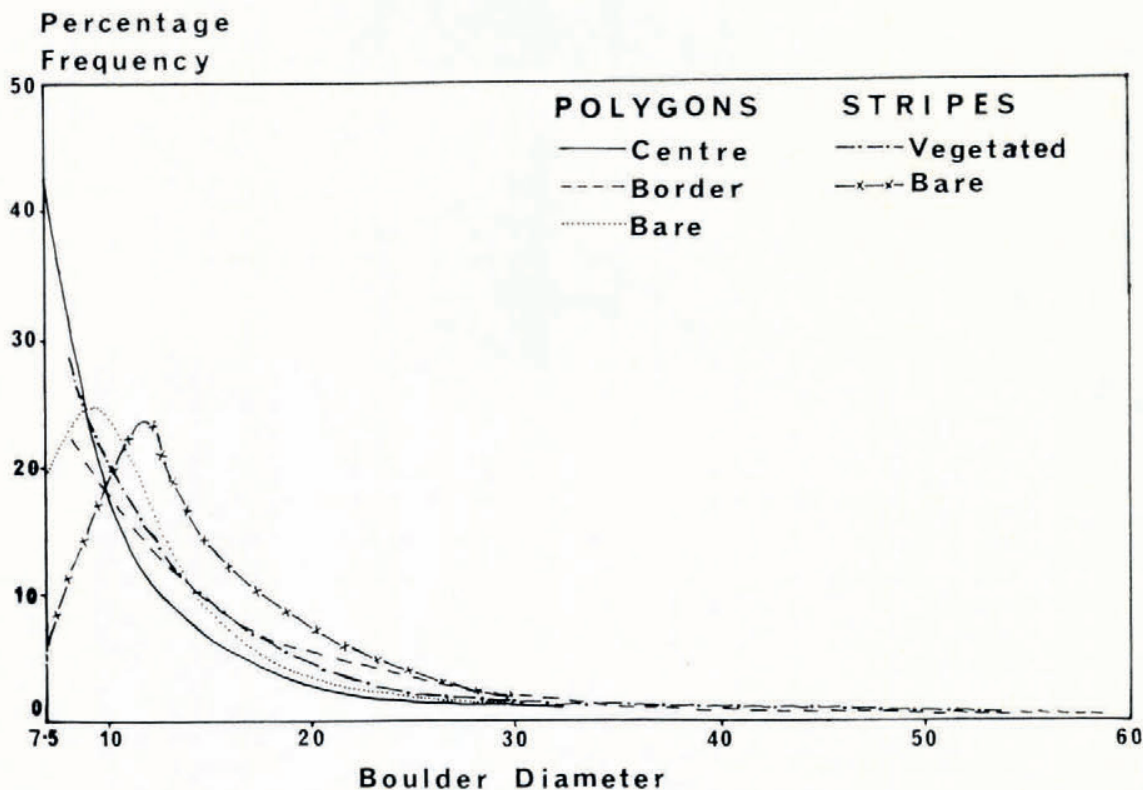

Fig. 5. Frequency curves for the boulder sizes of the centres and borders of vegetated coarse polygons, the borders of bare coarse polygons and vegetated and bare coarse stripes. Boulder diameter is in centimetres. 
TAble I. Means and standard deviations of Diameters and WIDTHS OF PATTERNED GROUND TYPES

Patterned ground

Coarse polygon centre Coarse polygon border Vegetated coarse stripe Bare coarse stripe Fine polygon centre Fine polygon border

$\begin{array}{cc}\begin{array}{c}\text { Mean } \\ \mathrm{cm}\end{array} & \begin{array}{c}\text { Standard } \\ \text { deviation } \\ \mathrm{cm}\end{array} \\ 98.0 & 76.2 \\ 69.9 & 48.0 \\ 334 & 127 \\ 149 & 84 \\ 69.6 & 37.8 \\ 30.5 & 14.8\end{array}$

A $\chi^{2}$ test was applied to the polygon-size distributions to ascertain whether there is justification in dividing them into two types: coarse and fine. Using a probability criterion of 0.005 , the distributions were found to be statistically different and are therefore probably produced by different processes and not merely due to age, when the types would probably be more transitional.

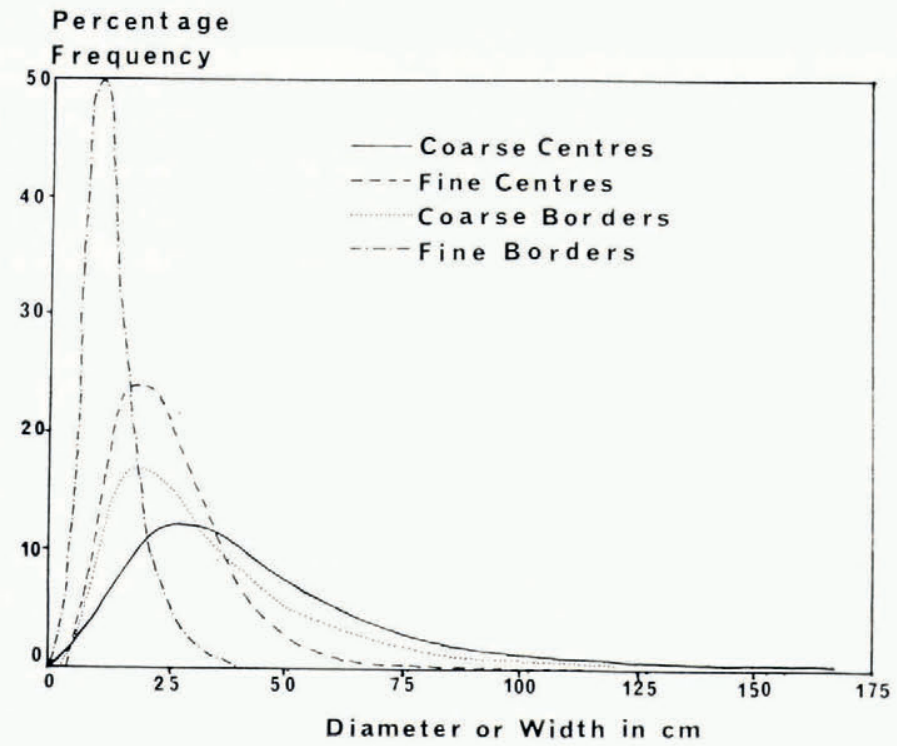

Fig. 6. Frequency curves for the diameters of the centres and widths of the borders of coarse and fine polygons.

\section{Movement investigation}

Attempts were made to observe the movement of both fine and coarse polygons. Some of the former were photographed and mapped on 9 October I $_{96}$. The polygons were then disturbed to three different depths (surficially, $15 \mathrm{~cm}$ and $30 \mathrm{~cm}$ ) in three adjacent areas. The whole area was then photographed and mapped, and photographed and mapped again, in the following spring and autumn. In the spring of I 966 (29 June), there was no sign of polygon re-formation but there was evidence of some movement, the amount of which is shown in Table II. The amount of movement between 29 June and 7 October 1966 is shown in Table III. It seems that the process of polygon formation (in the Cairngorm Mountains) is too slow to be able to see in what directions movement takes place. Nevertheless, it can be seen that not only boulders but soil also moves and that, in general, there is more movement over the period covered by Table II than that of Table III, which is also the period over which there are more fluctuations across the freezing point. 


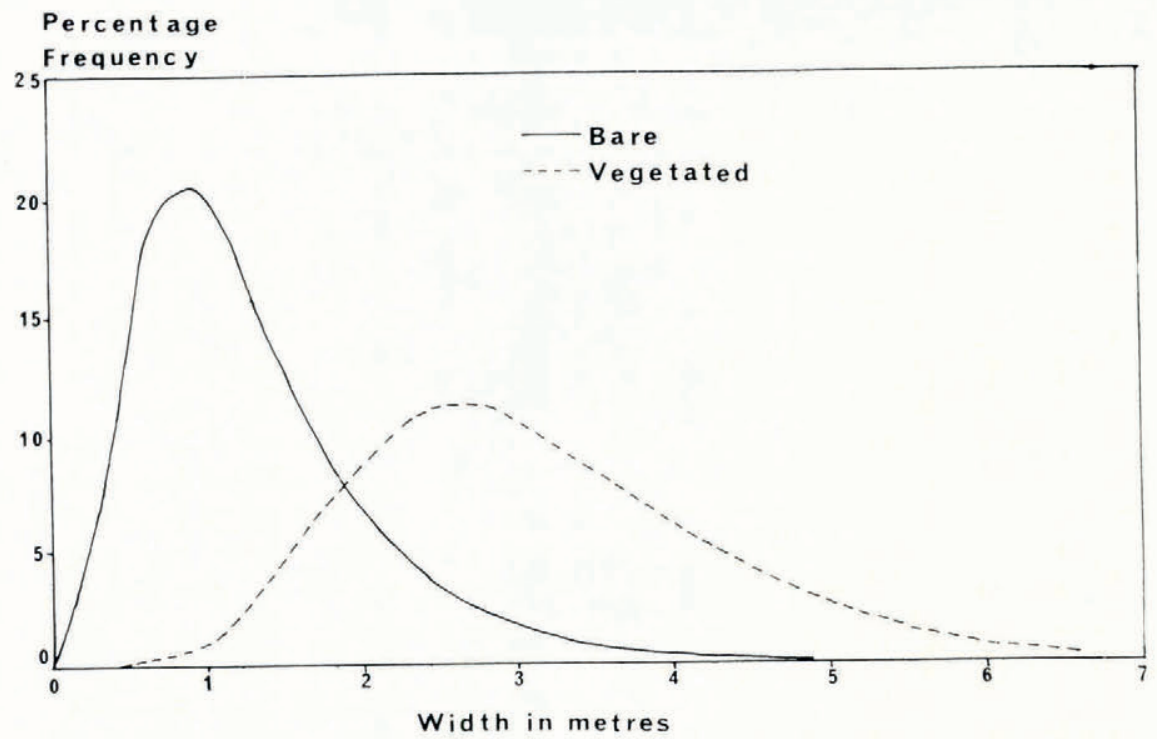

Fig. 7. Frequency curves for the widths of bare and vegetated coarse stripes.

TAble II. The Amount of movement of a fine polygon Between 9 October 1965 AND 29 JuNe 1966

\begin{tabular}{|c|c|c|c|c|c|c|c|c|c|c|c|}
\hline \multirow{3}{*}{$\begin{array}{c}\text { Depth } \\
\mathrm{cm}\end{array}$} & \multicolumn{4}{|c|}{ Soil } & \multicolumn{6}{|c|}{ Boulders } & \multirow{3}{*}{$\begin{array}{l}\text { Total number } \\
\text { of boulders }\end{array}$} \\
\hline & \multirow{2}{*}{ No. } & \multirow{2}{*}{$\begin{array}{l}\text { Covered } \\
\text { Maximum } \\
\text { distance } \\
\mathrm{cm}\end{array}$} & \multirow{2}{*}{ No. } & \multirow{2}{*}{$\begin{array}{l}\text { emoved } \\
\text { Maximum } \\
\text { distance } \\
\mathrm{cm}\end{array}$} & \multirow{2}{*}{ No. } & \multicolumn{2}{|c|}{$\begin{array}{l}\text { Linear } \\
\text { Maximum }\end{array}$} & \multirow{2}{*}{ No. } & \multicolumn{2}{|c|}{$\begin{array}{l}\text { Rotational } \\
\quad \text { Maximum }\end{array}$} & \\
\hline & & & & & & $\begin{array}{c}\text { Size } \\
\mathrm{cm}\end{array}$ & $\begin{array}{l}\text { Distance } \\
\mathrm{cm}\end{array}$ & & $\begin{array}{c}\text { Size } \\
\mathrm{cm}\end{array}$ & Angle & \\
\hline Surface & 7 & 6 & 4 & 36 & 4 & I 6 & 20 & 2 & 22 & $90^{\circ}$ & 34 \\
\hline 15 & 3 & 6 & 2 & 2 & 16 & 10 & 23 & - & - & $\overline{60}$ & $\begin{array}{l}33 \\
38\end{array}$ \\
\hline & - & - & 10 & 18 & 6 & 6 & I0 & 4 & 7 & $60^{\circ}$ & 38 \\
\hline
\end{tabular}

"Depth" refers to "depth of disturbance"; "covered" refers to "soil having covered stones"; "removed" refers to "soil having been removed from stones"; "linear" and "rotational" refer to type of movement in a horizontal plane; "No." refers to number of stones which have moved or have been covered or denuded by soil movement.

Table III. The Amount of movement of A fine polygon Between 29 June and 7 October 1966

\begin{tabular}{|c|c|c|c|c|c|c|c|c|c|c|c|}
\hline \multirow{4}{*}{$\begin{array}{c}\text { Depth } \\
\mathrm{cm}\end{array}$} & \multicolumn{4}{|c|}{ Soil } & \multicolumn{6}{|c|}{ Boulders } & \multirow{4}{*}{$\begin{array}{c}\text { Total number } \\
\text { of boulders }\end{array}$} \\
\hline & \multirow{3}{*}{ No. } & \multirow{3}{*}{$\begin{array}{l}\text { Covered } \\
\text { Maximum } \\
\text { distance } \\
\mathrm{cm}\end{array}$} & \multicolumn{2}{|c|}{ Removed } & \multirow{3}{*}{ No. } & \multicolumn{2}{|c|}{ Linear } & \multicolumn{3}{|c|}{ Rotational } & \\
\hline & & & No. & Maximum & & & zximum & No. & & imum & \\
\hline & & & & $\begin{array}{c}\text { distance } \\
\mathrm{cm}\end{array}$ & & $\begin{array}{l}\text { Size } \\
\mathrm{cm}\end{array}$ & $\begin{array}{c}\text { Distance } \\
\mathrm{cm}\end{array}$ & & $\begin{array}{l}\text { Size } \\
\mathrm{cm}\end{array}$ & Angle & \\
\hline Surface & 2 & 3 & 2 & 3 & 5 & 10 & 23 & 2 & 10 & $60^{\circ}$ & 34 \\
\hline I5 & 2 & 2 & - & - & 2 & 5 & Io & - & - & - & 33 \\
\hline 30 & - & - & 4 & 7 & 3 & 7 & 18 & $I^{v}$ & $3^{v}$ & $60^{\circ} \mathbf{v}$ & $3^{8}$ \\
\hline
\end{tabular}

"Depth" refers to "depth of disturbance"; "covered" refers to "soil having covered stones"; "removed" refers to "soil having been removed from stones"; "linear" and "rotational" refer to type of movement (rotation is in a horizontal plane except where demarcated by a "v" which refers to the vertical plane); "No." refers to number of boulders which have been moved or have been covered or denuded by soil movement.

Coarse polygons were disturbed in two different ways. In one area, the boulders and soil were thoroughly mixed up, and in the other the soil and vegetation were removed but the boulders were left. A third area was recorded and left unchanged. The disturbance took place on 9 October 1965 . There were no changes when the areas were investigated again on 29 June and 7 October 1966 , except for some aeolian removal of vegetation. 


\section{Pipkrake}

A large number of hypotheses have been put forward to explain patterned ground, most of which have been summarized by Washburn (I956), who pointed out that different hypotheses probably apply to different environments. He also suggested that, in any particular environment, the explanation is probably polygenetic.

There are three main groups of hypotheses: those embodying heave (e.g. Hamburg, I9ro), convection (e.g. Bénard, I9oo; Gripp, 1926) and contraction (e.g. Figurin, I 823; Baer, I837; Cholnoky, I9I I). The surficial nature of the patterned ground in the Cairngorm Mountains, however, rules out convection. Nearly all of the hypotheses depend on freeze-thaw oscillations and some observations were therefore made during such a period.

Practically the whole surface of the ground (where denuded) was covered with pipkrake. In a small area $(60 \mathrm{~cm}$ by $60 \mathrm{~cm})$, the largest diameters of a hundred stones were measured and it was recorded whether they had been raised by pipkrake, which on the day of observation grew to a maximum of $4 \mathrm{~cm}$, upturned or left in situ. The smallest diameter measured was $1.25 \mathrm{~cm}$ and the largest was $16.5 \mathrm{~cm}$. It was found that 46 stones were uplifted, 38 left in situ and 16 upturned. The mean diameter of those raised was $2.79 \mathrm{~cm}$; the mean of those left in situ was $6.27 \mathrm{~cm}$ and the mean of those upturned was $6.5^{8} \mathrm{~cm}$. Their respective standard deviations were $1.04,2.79$ and $3.5^{8} \mathrm{~cm}$. A $\chi^{2}$ test showed that there is a greater than $99.5 \%$ statistically significant difference between the distribution of raised stones and those left in situ.

Measurements were also taken of the movement of stones with an axial ratio greater than or equal to $2:$ I to see whether they have any propensity for upturning rather than uplifting in toto. The sizes of the stones ranged from 1.25 to $10 \mathrm{~cm}$ and the average size of the pipkrake was $2.5 \mathrm{~cm}$. I 7 stones were not moved at all, $4 \mathrm{I}$ were upturned and 42 were uplifted in toto, which suggests that elongated stones have an equal propensity for upturning as uplifting in toto. Nevertheless, if these figures are compared with the ones in the previous paragraph, it can be seen that a greater proportion of elongated stones is upturned than those of other shapes.

It was also noticed that pipkrake not only raised stones and fines vertically (lending support to the heave hypotheses) but also moved them away from the larger unmoved stones (supporting the contraction hypotheses). Some of the stones fell into the gaps formed between the unmoved stones and the soil, and after the pipkrake had melted stones were often seen surrounding larger stones or boulders.

\section{SugGeSTED ORIGIN OF FINE POLYGONS}

Hollows can be seen around boulders of the size of those forming fine polygon borders, and smaller boulders or stones are seen lying in these hollows usually orientated parallel to the larger boulder's periphery. In the borders of fine polygons, small boulders are also often found surrounding and orientated parallel to the periphery of the larger ones. Where the smaller boulders or stones lie touching the larger ones, they usually rest against the latter; but away from the boulder, the smaller boulders or stones tend to dip towards the larger ones as if they have been uplifted, while the larger ones remain stationary.

This observation was tested as follows: the angle of inclination of boulders in polygon borders was measured from the same four polygons as were used for the measurement of boulder diameters. Measurements were taken to the nearest degree of boulders with a minimal axial ratio of $3: 2$. The distribution is shown in Figure 8. The mean angle of dip was found to be $36^{\circ}$ with a standard deviation of $21^{\circ}$.

Although pipkrake have been proposed as a cause of patterned ground (Salomon, I929, p. 9), the largest recorded stones raised by pipkrake were only the size of hens' eggs (Philberth, 1964, p. г66). However, larger stones can be raised by ice lenses (Philberth, 1964, p. I22; 
Everett, I966, p. 217). Although ice lenses were not seen by the author in the Cairngorm Mountains, they have been observed by Caine (1963, p. 1 74) in the Lake District, and there is therefore presumably no reason why they could not occur in the Cairngorm Mountains.

The evidence seems to suggest that large boulders remain stationary while the soil and smaller boulders and stones are heaved. This hypothesis was tested as follows: in an area of fine polygon development, the sizes of 6 o boulders displaying lichen (i.e. presumably immobile) were compared with the sizes of 60 boulders without lichen. The mean diameter of the lichencovered boulders is $7 \mathrm{I} .4 \mathrm{~cm}$ with a standard deviation of $34.8 \mathrm{~cm}$, and the mean diameter of the bare boulders is $57.2 \mathrm{~cm}$ with a standard deviation of $26.2 \mathrm{~cm}$. A $\chi^{2}$ test showed that there is a greater than $99.5 \%$ statistically significant difference between the two distributions.

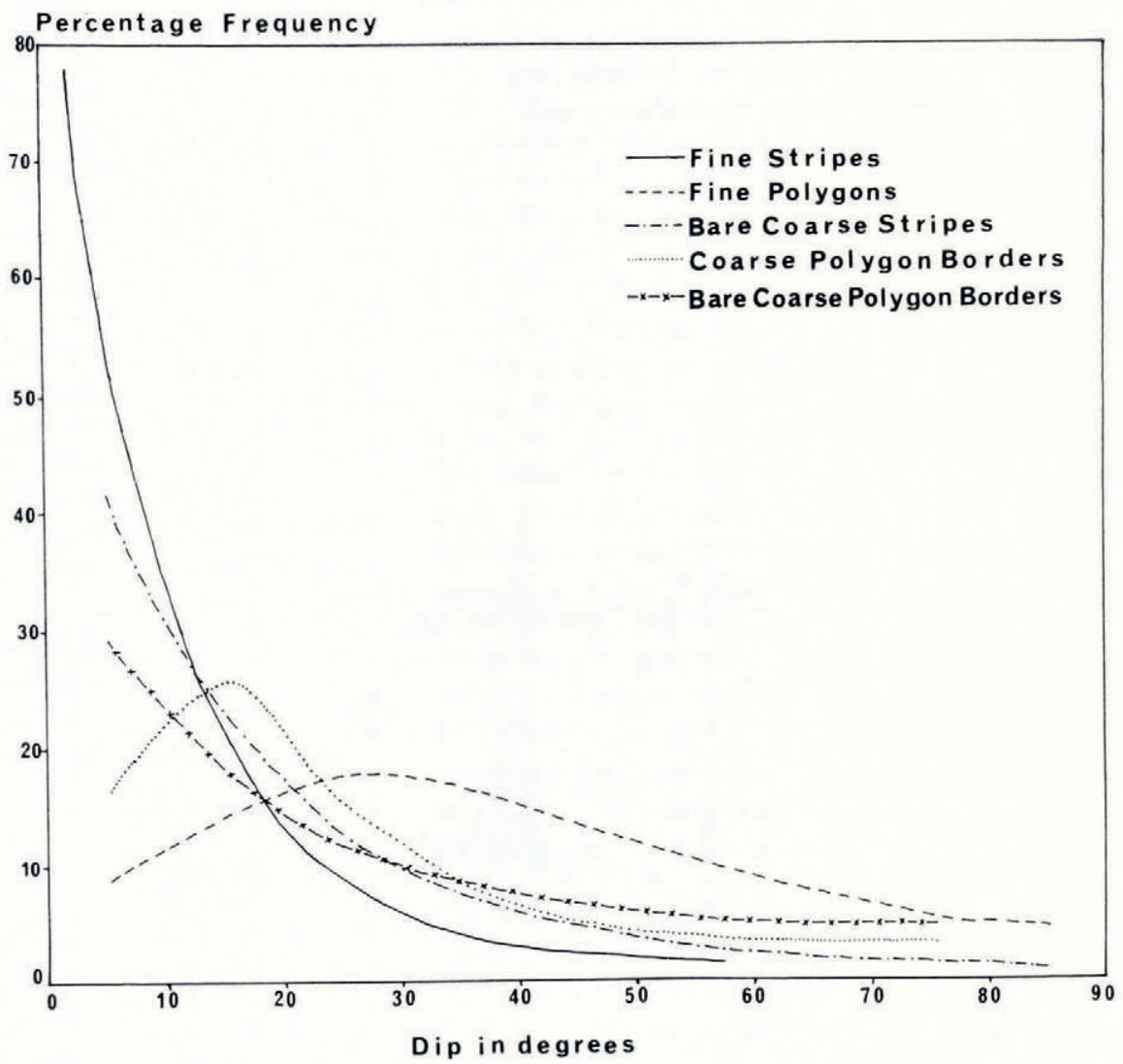

Fig. 8. Frequency curves, plotted in frequency groups of $10^{\circ}$ of boulder dips in the borders of fine, coarse vegetated and coarse bare polygons, and of fine and bare coarse stripes.

The minimal size of stationary boulders is probably proportional to the amount of heave. Not only are polygon centres upheaved but they also contract away from large boulders, if the evidence of pipkrake observations can be applied to other types of heave. The contraction is probably due to soil desiccation, since the water content is largely extracted to form ice. Some stones will fall, as an immediate result of upheaval of the centre, into the gaps round the large boulders. Other boulders will slide radially down the domed surface of heave probably at the immediate onset of thawing when the surface will be most lubricated and before the centre has subsided. 
In an area of uniform soil and boulder content, polygon sizes will be proportional to the spacing of stationary boulders; the greater the heave, the larger the size of stationary boulders and, in general, the larger the polygon size. This reasoning conforms with that of Troll (1944), who pointed out that the size of patterned ground is roughly proportional to latitude. He stated that the large high-latitude forms have a larger period and greater amount of heave than the low-latitude forms.

\section{SUGGESTED ORIGIN OF COARSE POLYGONS}

If the centres of coarse polygons were heaved, a radial orientation of the boulders found in the centre would be expected. Orientation measurements were therefore taken from the centres of four coarse polygons but no radial orientation was revealed.

The dips of the boulders in the polygon borders were also measured (Fig. 8). The mean angle of dip is $30^{\circ}$ with a standard deviation of $22^{\circ}$. A $\chi^{2}$ test indicated a $90 \%$ statistically significant difference between the dips of boulders in the borders of fine and coarse polygons, suggesting that the borders of coarse polygons dip at a significantly lower angle than those of fine ones.

Coarse polygon sizes also have a higher relative dispersion $(77.7 \%)$ compared with fine polygons $(54.5 \%)$. A closer examination reveals that coarse polygons formed from porphyritic granite are not as well developed, contain smaller boulders and have greater diameters than those formed from the more widespread coarse-grained granite. The mean diameters of polygons formed from porphyritic and coarse-grained granite are 145.3 and $79.0 \mathrm{~cm}$, respectively, with respective standard deviations of 87.7 and $34.3 \mathrm{~cm}$, and a $\chi^{2}$ test showed that there is a $99.5 \%$ statistically significant difference between the two distributions.

The lack of orientation and relatively low angle of boulder inclination suggest a different origin to that postulated for fine polygons and, in fact, suggest lack of movement. The hemispherical cross-section, high relative size dispersion (Elton, 1927, p. 82) and lithological dependence could all be explained by selective weathering which has already been suggested elsewhere as a possible cause of patterned ground (Meinardus, 1912, p. 254-55). Sorting can be explained by the probability that small boulders and stones will decrease in size as a result of frost shattering faster than large ones, because of their greater surface area to volume ratio. Boulders of fine-grained porphyritic granite are also more subject to frost shattering than those of coarse-grained granite (Waters, r 964 , p. 79) and consequently are smaller and the polygons formed by them contain more fines and are therefore larger.

Mention has also been made of coarse polygons with bare centres. Figure 8 shows that their boulder-dip distribution can be fitted to a second-degree logarithmic curve, which suggests a force influencing smaller boulders parallel to the ground surface. Their topographic position (i.e. valley bottom) suggests that they may be part of a solifluction deposit, and the presence of polygons on this deposit indicates that coarse polygons can form with no pronounced boulder inclination, explicable under a weathering hypothesis. However, the steeper inclination than other solifluction features (i.e. stripes) suggests that there is probably some heaving, as may also be true, in the past, for vegetated polygons.

\section{SUGGESTED ORIGIN OF STRIPES}

The inclinations of stones in four fine stripes were measured to the nearest degree. 25 stones were measured from each stripe. The mean inclination was found to be $\mathrm{I}^{\circ}$ and the distribution could be fitted to a second-degree logarithmic curve (Fig. 8) whose equation is $\log y=\mathrm{I} .77-0.88 \mathrm{I} x+0.0574 x^{2}$, which has a high constant term and a low coefficient of $x$, both indicating a high proportion of stones with a low inclination. Many of the stones are, in fact, roughly parallel to the slope of the ground, suggesting laminar down-slope movement 
or solifluction. The orientation of stones in a horizontal plane was also measured and is represented by Figure 9, in which the only pattern that seems to exist (if any) is a decrease from $0^{\circ}$ to $25^{\circ}$, a rise between $25^{\circ}$ and $80^{\circ}$ and a low $80-90^{\circ}$ value. This could possibly be explained by relative down-slope movement of soil and stone stripes. Any stone projecting out of the stone stripe by more than $25^{\circ}$ in an up-slope direction will be affected by the downslope movement of the soil stripe and possibly become wedged in a new orientation. Stones projecting at about $90^{\circ}$ or any orientation in a down-slope direction will be reduced to low angles of deviation.

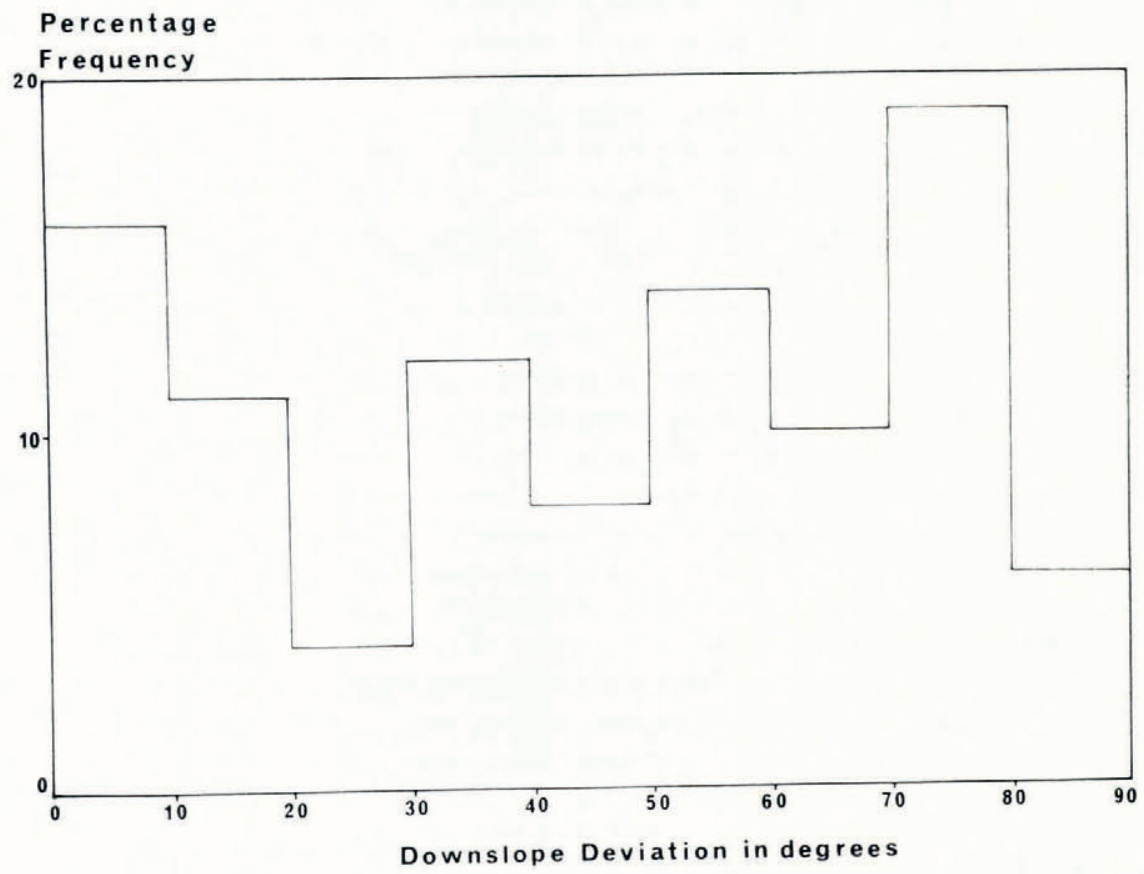

Fig. 9. Histogram of the orientation of stones in fine stripes.

It would appear, therefore, that fine stripes are governed by solifluction, as suggested by Nordenskjöld (I909, p. 63), and that soil stripes move faster than stone ones because solifluction decreases with depth, and the stones which extend below the ground surface move more slowly than the soil. This might also explain why so few fine stripes were found, since they can only be found where all the stones are small, i.e. less than about $15 \mathrm{~cm}$, because any larger boulders would extend below the present layer of active solifluction and thus the soil will be dammed up-slope behind them producing small terraces, which are indeed often found.

Stone orientations of bare coarse stripes were also measured from four localities. The dip distribution is shown in Figure 8 from which it can be seen that its curve is flatter than that for fine stripes, probably because of interactions between boulders of different sizes; nevertheless, the second-degree logarithmic rather than logarithmic normal shape suggests predominant down-slope rather than cross-slope influence. Movement of soil and boulders down-slope would obey the laws of viscosity so that movement is slowest at, and down-slope from, the larger stationary boulders and fastest as well as deepest midway between them. The effect of this is that coarse material is deposited both up-slope and down-slope from the stationary 
boulders and the stripe form is developed. Evidence to support this sorting by viscous flowage has been provided by the experiments of Dzulynski and Walton (1963).

The correlation coefficient between altitude and width of vegetated coarse stripes is -0.976 , which is $97.5 \%$ statistically significant. Altitude is most likely inversely proportional to age or movement periodicity. Thus there appears to be a correlation between movement periodicity and size. Low-altitude movement is likely to take place at climatic extremes when solifluction extends to considerable depth and large boulders will be moved, boulders which under a less arduous climate would extend below the active layer and remain immobile. It seems, therefore, as with fine polygons that large immobile or relatively slower-moving boulders form the coarser, now bare stripes, while the finer material flows past, to form the finer, now vegetated stripes.

AgE

The technique of lichenometry was used to assess the age of coarse polygons and stripes. Using a similar method of measuring lichen to that used by Sugden (unpublished, p. 2 I9) and assuming a growth rate of $46 \mathrm{~mm}$ per century, which Bornfeldt and Osterborg (unpublished) found in southern Norway, a climate approximating that of the Cairngorm Mountains, it was inferred that coarse polygons and stripes were active in the eighteenth or nineteenth centuries (Table IV). The results cannot be considered conclusive because of the likelihood of overcrowding and the probability that the lichen may be $n$th generation since the boulders were originally denuded or stabilized. Since some coarse polygons (the bare ones) appear to be active today, the vegetated ones were probably active in a climatic period not very much more extreme than today. Furthermore, if they were much older, they would probably be completely covered by vegetation as are the vegetation-covered lobes which are thought to date from zone IV (King, in press). Completely vegetated polygons may exist but, without excavation and boulder-diameter measurement, they are unrecognizable.

Table IV. Lichen measurements. The degree of accuracy was CALCULATED FROM THE RANGE OF THE FIVE LARGEST THALLI

$\begin{array}{lccc}\text { Patterned ground } & \begin{array}{c}\text { Altitude } \\ \mathrm{m}\end{array} & \begin{array}{c}\text { Mean maximal } \\ \text { lichen diameter } \\ \mathrm{mm}\end{array} & \begin{array}{c}\text { Date } \\ \text { A.D. }\end{array} \\ \text { Coarse polygon } & \text { I } 110 & 67 & \mathrm{I} 820 \pm 20 \\ \text { Coarse polygon } & \text { I } 160 & 63 & 1830 \pm 60 \\ \text { Coarse polygon } & \text { I } 280 & 63 & 1830 \\ \text { Coarse stripe } & 760 & 85 & 1780 \pm 20 \\ \text { Coarse stripe } & 880 & 72 & 1800 \pm 90 \\ \text { Coarse stripe } & 960 & 105 & 1740 \pm 50\end{array}$

\section{Acknowledgements}

I should especially like to thank Dr J. B. Sissons of the Department of Geography, University of Edinburgh, for providing me with invaluable advice throughout my research. I am grateful to the Natural Environment Research Council for awarding me a grant towards my research. My thanks are also extended to the Aviemore Police for concerning themselves about my welfare when I was camping.

MS. received 3 April 1970 and in revised form I2 March 197 I 


\section{REFERENCES}

Baer, K. E. von. I837. Expédition à Novaia-Zemlia et en Laponie. Tableau physique des contrées visitées. Troisième article. Vegetation et climat de Novaia-Zemlia. Académie Impériale des Sciences, St. Pétersbourg. Bulletin Scientifique, Tom. 3, p. 171-91.

Bénard, H. rgoo. Les tourbillons cellulaires dan une nappe liquide. Revue Générale des Sciences Pures et Appliquées, Tom. 1 I, No. 23, p. 126I-7I.

Bornfeldt, F., and Osterborg, H. Unpublished. Lavarter som hjälpmedel för datering av ändmoräner vid norska glacïärer. [Report, Naturgeografiska Institutionen, Stockholm, 1958.]

Caine, T. N. 1963 . The origin of sorted stripes in the Lake District, northern England. Geografiska Annaler, Vol. 45 , Nos. $2-3$, p. $172-79$.

Cholnoky, E. von. 19гі. Spitsbergen. Földrajzi Közlemények (Nemzetközi Kiadós (International Edition)), Vol. 39,

p. 93-134.
Dzulynski, S., and Walton, E. K. 1963. Experimental production of sole markings. Transactions of the Edinburgh Geological Society, Vol. 19, Pt. 3, p. 279-305.

Elton, C. S. 1927. The nature and origin of soil-polygons in Spitsbergen. Quarterly Journal of the Geological Society of London, Vol. 83 , No. 330, Pt. 2, p. 163-94.

Everett, K. R. ig66. Slope movement and related phenomena. (In Wilimovsky, N. J., and Wolfe, J. N., ed. Environment of the Cape Thompson region, Alaska. Oak Ridge, Tenn., U.S. Atomic Energy Commission, Division of Technical Information Extension, p. 172-220.)

Figurin, A. E. 1823. Izvlecheniye iz zapisok mediko-khiruga Figurina, vedënnykh vo vremya opisi beregov severo-vostochnoy Sibiri [Extract from the notes of the physician-surgeon Figurin, made at the time of the inventory of the shores of north-eastern Siberia]. Zapiski izdavayemyye Gosudarstvennym Admiralteyskim Departamentom [Notes published by the State Admiralty Department], Chast' 5, p. 259-328.

Gripp, K. 1926. Über Frost und Strukturboden auf Spitsbergen. Zeitschrift der Gesellschaft für Erdkunde zu Berlin, Bd. 6 o, Ht. $7-8$, p. $35^{\mathrm{I}-54}$.

Hamberg, A. 1910. Gesteine und Tektonik des Sarekgebirges nebst einem Überblick der skandinavischen Gebirgskette. Geologiska Föreningens $i$ Stockholm Forhandlingar, Vol. 32, Ht. 4, No. 270, p. 68I-724.

King, R. B. In press. Lobes in the Cairngorm Mountains, Scotland. Biuletyn Peryglacjalny, No. 21.

King, R. B. Unpublished. Periglacial features in the Cairngorm Mountains. [Ph.D. thesis, University of Edinburgh, I968.]

Meinardus, W. I912. Beobachtungen über Detritussortierung und Strukturboden auf Spitzbergen. Zeitschrift der Gesellschaft für Erdkunde zu Berlin, Bd. 46, Ht. 4, p. ${ }^{250-59 .}$

Nordenskjöld, O. Igog. Die Polarwelt. Leipzig and Berlin, B. G. Teubner.

Philberth, K. I964. Recherches sur les sols polygonaux et striés. Biuletyn Peryglacjalny, Nr. 13, p. $99^{-1} 9^{8}$.

Salomon, W. 1929. Arktische Bodenformen in den Alpen. Sitzungsberichte der Heidelberger Akademie der Wissenschaften, Mathematische-naturwissenschaftliche Klasse, I929, No. 5 .

Sugden, D. E. Unpublished. Aspects of the glaciation of the Cairngorm Mountains. [D.Phil. thesis, University of Oxford, 1965.]

Tricart, J. 1967. Traité de géomorphologie. Tom. 2. Le modelé des régions périglaciaires. Paris, Société d'Édition d'Énseignement Supérieur.

Troll, C. I944. Strukturböden, Solifluktion und Frostklimate der Erde. Geologische Rundschau, Bd. 34, Ht. 7-8,

p. $545^{-694 .}$
Washburn, A. L. I 956 . Classification of patterned ground and review of suggested origins. Bulletin of the Geological Society of America, Vol. 67, No. 7, p. 823-66.

Waters, R. S. I964. The Pleistocene legacy to the geomorphology of Dartmoor. (In Simons, I. G., ed. Dartmoor essays. Exeter, Devonshire Association, p. 73-96.) 